\title{
NGOS INCOME GENERATION SERVICES AND RURAL WOMEN EMPOWERMENT IN RWANDA: A CASE OF CARE INTERNATIONAL IN HUYE DISTRICT, ISARO PROGRAMME
}

\author{
Magnifique UWANDINDA ${ }^{1 *}$, Mercylin KAMANDE ${ }^{2}$, \\ ${ }^{*}$ School of Social Sciences, Public Administration and Management, Community Development and NGO Management, \\ Mount Kenya University, Kigali, Rwanda \\ ${ }^{2}$ Mount Kenya University
}

*Corresponding Author: -

\begin{abstract}
: -
The main intention of this research was to analyze the role of NGOs income generating service and empowerment of rural women in Rwanda with a case of care international in Huye district, the Isaro program. The investigator used the interview guide, questionnaire and observation to collect information from the primary respondents and the field in general. Bouchard Formula was used to draw 97 respondents from target population of 2015 people (5 employees of Isaro Programme and 2010 rural women) including 5 respondents who are employees of Isaro Programme and 92 respondents who are direct beneficiaries of Isaro Programme applied both simple random and census as sampling techniques. The collected information was analyzed using multiple linear regression and correlation analysis by use of SPSS 21.0 version. The findings showed that $83(85.6 \%)$ of respondents strongly agreed that the Isaro programme offers capacity building through training, 84 (86.6\%) of respondents strongly agreed that Isaro program offers access to credit, 85 (87.6\%) of respondents that the Isaro programme has group saving scheme as a service offered to rural women, 84 (86.6\%) of respondents strongly agreed that Isaro programme offers mutuelle de santé as a service to rural women, 76 (42.3\%) of respondents before joining Isaro programme saved seasonal average of money from 0 to 10000 Rwf to rural women, 25 $(25.8 \%)$ of respondents after joining Isaro programme saved seasonal average of money from 40000 to $50000 \mathrm{Rwf}$ to rural women. The results have also prove that there is there is a relationship between group saving scheme and participation in family economic development services which has Pearson correlation of 0.731 and calculated significance value which is 0.00 lesser than 0.05 level of significance, between the group savings scheme and participation in decision making at family level which has $r=0.822$ and sig=0.00 calculated significance value which is lesser than 0.05 significance level, between the group saving scheme and livelihood development which has a Pearson correlation of 0.671 and calculated significance of 0.00 that is less than the significance level of 0.05 significance level, between accessibility to credit and capacity building through training that has a Pearson correlation of 0.711 and the calculated significance value is 0.00 which is lesser than 0.05 significance level $(p=.711$ and sig $=.000<0.01$ level of significance. In conclusion, the results of the study have revealed that NGOs income generating services play a significant role in empowering rural women in Rwanda.
\end{abstract}

Keywords: - NGOs, Income Generating Services, Rural women, empowerment, CARE International, Isaro Programme, Rwanda

\section{(a) $(\$)$}




\section{INTRODUCTION}

Women play a key position in household and society, but in all necessary areas of life, females remained at great disadvantage compared to men (Shalakha \& Shivani, 2016). Traditionally, women's roles and roles are limited to household chores and agricultural services. typically engage them in work for extra time than men (14-16 hours versus to 7-9 hours for men) per working day (Roshani, 2010). In addition, they have confined accessibility to education, employment and decision-making process which hinders the empowerment of women. But, if it would be solved it would contribute much to women's empowerment and capacity-building in society because women are mothers of communities (Carson \& Randall, 2013).

According to Pyakuryal and Suvedi (2000), it was erroneously assumed that men and women had been equally benefited through development services. As a result, the women keep their backs to the men in all development services. CARE (2008) asserted that traditional Rwandan society made women and women dependent on men having no access to and managing economic assets. With regard to promote women's financial empowerment, the Rwandan government seeks to ensure that women, all rural women, gain equal access to and management of economic opportunities such as employment and credit (MIGEPROF, 2011). The policies concerned with women's empowerment puts an emphasis on the need to enhance partnerships between governmental and nongovernmental institutions, CSOs, and the private sector for growth the agenda to enhance the women's reputation in Rwanda

The government's dedication to promote gender equality at all levels, practices and discriminatory attitudes against women persist. This can have intense implications for efforts to improve the economic and economic reputation of women. Therefore, it is essential to extend the awareness campaigns and communicate with key stakeholders to create a better better perception that women has right for gender equality and good to boost both economic development and growth (ADBG, 2008).

The three problems for women empowering in African Countries and specifically in Rwanda are the traditional roles played in the African society which are confined to family chores and farming services, discriminatory traditional practices and attitudes against women which persist and finally the failure for a huge number of NGOS which are initiating and executing the income generating services that targets women to change the Rwandan society mindsets towards women empowerment.

These problems could be the major causes of underdevelopment and poverty in most of African countries and particularly in Rwanda. The role played by women in the development process is ignored despite the burden of taking care of households' needs (food, education, health, etc.) although they are married. The attitude of the majority of men is negative regarding family needs satisfaction. In most African societies women represent a huge percentage therefore; they deserve attention from Politicians to improve their earnings and consequently participating actively in the development process. The current study is meant to examine the role of NGOs income generating programme on rural women empowerment in Rwanda, Care international in Huye District, Isaro Programme.

\subsection{Objectives of the study}

\subsubsection{General objective}

The main objective of this research is to examine the role of NGOs income generation services on rural women empowerment of rural women in Rwanda, a case of Care International in Huye District Isaro Programme.

\subsubsection{Specific objectives}

(i) To examine the income generating services offered to women in ISARO Programme.

(ii) To assess the effect of ISARO Programme on level of income and improved livelihood.

(iii) To examine rural women's involvement in decision making before and after joining CARE international, ISARO Programme.

\section{Review of Literature \\ 2.1 Empirical Review}

Non-governmental organizations organize training services for income-generating services (IGSs); some of the nongovernmental organizations advantages and functions are that they are capable to participate and mobilize the poor and the communities in remote areas; they assist empower poor humans to gain control their lives, and work with local institutions that carry out the projects with low cost and more efficiently than government organizations and promote sustainable development (Manju, 2014).

The emergence of microcredit is rightly identified as a tool for real looking success for equitable and sustainable development. The empowerment of women through microcredit packages supporting businesses such as Grameen Bank and BRAC is properly recorded (Hunt \& Kasynathan, 2002). NGOs, such as the Forum for Women Educators in Africa, based in Nairobi, have held a big role by means of making sure that quality education for all and the intention of parity and gender equality in African education. Study from Mushumbusi and Kratzer (2013) in Tanzania proved that there is a significant difference between women contributors of microfinance benefits who generate services and those who are not members. The results have also proved that women contributors have more control over savings, earnings, income generating business, making decision as a role, freedom of mobility, self-esteem and self-efficacy and increased activities outside home.

The study conducted by Thanabalasingam and Asankha (2014) has revealed that that NGO intervention in poverty alleviation programs has led to a considerable development in the living standards of people in Sri Lanka. This research has positioned a lot of emphasis on elements such as family income, health and education facilities that have improved 
due to the fact that the introduction of NGO activities. The consequences of the statistical estimate have similarly indicated that the level of households' academic background has an amazing impact on the benefits of households in fighting against poverty.

Research by Rana, Ali, and Sara (2012) confirmed that women's empowerment is remarkably influenced by way of the capability with age, the education of the husband; the belongings inherited from the father, marital status and the amount of microfinance. The study became two subsets that show where the personal loan is used and where the loan is used by the family members, such as the husband, father, or head of household. Salma, et al., (2020) stipulated that the mission of improvement through authorities and NGOs has performed a necessary role to providing training, awareness and credits to rural women which raised the economic standards of their families and that of South and North regions of Pakistan.

Thus, this research by Rana, Ali, and Sara (2012) concluded that women who use the loans by themselves have higher microfinance effects on empowerment as compared to loans used through different family members. Based on the results of this studying through the use of Rana, Ali, and Sara (2012), microfinance has been proven to have a recommended effect on women's empowerment but they are not as expected. This research offers a suggestion that microfinance institutions want to tighten and increase their help to women for their empowerment, which have an effect on the livelihood of the whole family.

The research conducted in Tanzania by Mushumbusi and Kratzer (2013), using both qualitative and quantitative data, have shown that members of microfinance institutions (MFIs) who are women are more empowered compared to nonmembers. The findings indicated that there is a considerably difference between women who are members of MFIs and non-members in the elements associated to women's empowerment, where the outcomes showed that women participating in MFIs have a remarkable management on the financial savings and profits generated from business, increased role in decision-making, larger self-efficacy and self-esteem, increased freedom of mobility and extended out of doors outdoor things to do that elevate livelihoods of their families.

Noreen (2011) has attempted to examine the role of microfinance in empowering the female population of Bahawalpur district, Pakistan. The intention of the study used was to look at the socioeconomic determinants of women's empowerment in which microfinance is a key economic determinant. This research assessed the analysis of regression often based primarily on Bahawalpur City to demonstrate the relationship of specific socioeconomic determinants in women's empowerment. Women's empowerment is measured by organizing a simple index of five indications associated with child health, education, the choice of children's spouse, the purchase of primary goods, and decisions about use of the loan. The results show that women's empowerment is influenced with the help of husband's age and education; the property inherited from the father, the marital status and microfinance.

A research carried out by Mukamana (2012), revealed the unique offers they provide to artisans and which include education to enhance improvement and set up truthful prices, facilitating accessibility to the international and nearby market, educational training in marketing and business management, economic training, self-confidence and management.

The results have shown that all the services have strengthened the contribution of craftswomen to the financial gains of their respective homes, which has allowed them to acquire some productive property and improve their socio-political positions at the local level and community level. However, research has established that gender imbalances in some households forestall married women from continuing their careers with the equal simple task that the time they can pick out to devote to craft activities is dedicated to chores of households.

\subsection{Research Gap}

The fewer previous empirical researches conducted in this field of NGO income generating service and rural women empowerment has given less attention the contribution of rural women empowerment in the sense of enhancing the participation of women in family economic development activities, participation in family decision making and participation in improving the livelihoods of family members. For instance the research of Thanabalasingam and Asankha (2014) has focused on the impact of NGOs intervention on poverty reduction: Empirical evidence from rural Sri Lanka whereas the research of Rana, Ali and Sara (2012) has concentrated on empowering women through microfinance: Evidence from Tanzania. Thus, this shows that NGOs income generating services enhance the increase in empowerment like access to credits, training and group saving scheme was also given less attention.

A research done by Mukamana (2012) in Uganda found that the different services have been shown to the craftswomen together with training in product development, pricing fairly, marketing and business and the craftswomen have obtained a decision that strengthens their households in regarding the use of family income. Kantor (2003) emphasizes that increasing accessibility to income generating opportunities is a mean to facilitate women's empowerment. However, getting access to economic resources do not empower only women, but also accesses to materials (credit, property and money), human and social (education, business) resources.

This shows that studies lack the exact measures for how to assess women's empowerment through IGPs. The intended study finds its room to come up with its own kind of analytical frame to assess the influence of NGOs on rural women empowerment in Huye District taking CARE International in its ISARO programme as a case study.

\section{Materials and Methods}

The study used descriptive research design which contributes to the rationalization of the characteristics of the target population who direct beneficiaries of Isaro Programme and employees of Care international Rwanda, specifically of Isaro Programme in Huye District. The study embraced quantitative and qualitative data from primary sources with the 
help of questionnaires and secondary source with help of reports in order to capture both numerical data (numbers and figures) and qualitative data (narrative) by use research questionnaire, interview guide and observation as tools for data collection.

The application of Buchards (1992) formula on rural women as target population of 2010 people revealed that 92 respondents of rural women participated in this study. The whole respondents in the research has been 5 respondents as employees of Care international, Isaro Programme and 92 respondents from the whole population of rural women who are beneficiaries of Isaro Programme to increase the number of respondents to 97 respondents

The sample of 97 respondents were selected from 2,015 ISARO programme staff and 2,010 rural women involved in the programme. In the stratified sampling technique, the researcher used a random sampling which is simple random sample to make sure that the 97 respondents of the study have equal chance to participate in this research.

After the process of data collection and processing, these data were analyzed using descriptive statistics and inferential statistics analysis with the use of version 21.0 of SPSS. Data on the use of quantitative and qualitative statistical approaches and strategies have been analyzed. Descriptive statistical tools were used to analyze quantitative data. The statistical measures have been used to summarize and classify research data into tables, percentages, and frequencies and correlation and regression analysis tables. The the model of regression coefficient $Y=\beta_{0}+\beta_{1} X_{1}+\beta_{2} X_{2}+\beta_{3} X_{3}$ were $Y$ represents the dependent variable which is rural women empowerment while $\beta$ 's are the coefficients of determination while $\mathrm{X} 1, \mathrm{X} 2, \mathrm{X} 3$ are predictors of NGOs Income generating service which are group savings scheme, access to credit and training.

\subsection{Income Generating Services offered to rural women in Isaro programme}

Table 4. 1: Income Generating Services offered to rural women in Isaro Programme

\begin{tabular}{lllllll}
\hline $\begin{array}{l}\text { Perceptions on } \\
\text { Services }\end{array}$ & $\mathbf{5}$ & $\mathbf{4}$ & $\mathbf{3}$ & $\mathbf{2}$ & $\mathbf{1}$ & Mean \\
\hline $\begin{array}{l}\text { Capacity building } \\
\text { training }\end{array}$ & $0(0.0)$ & $2(2.1 \%)$ & $2(2.1 \%)$ & $10(10.3 \%)$ & $83(85.6 \%)$ & 1.206 \\
Access to credit & $0(0.0)$ & $1(1.0 \%)$ & $2(2.1 \%)$ & $10(10.3 \%)$ & $84(86.6 \%)$ & 1.175 \\
Group savings & $0(0.0)$ & $2(2.1 \%)$ & $2(2.1 \%)$ & $8(8.7 \%)$ & $85(87.6 \%)$ & 1.185 \\
scheme & & & & & & 1.188 \\
Total mean & & & & & & \\
\hline
\end{tabular}

\section{Source: Primary Data, 2021}

The Table 4.1 showed that 1.206 and $83(85.6 \%)$ of respondents strongly agreed that Isaro programme offers capacity building through trainings. The mean of 1.175 and $84(86.6 \%)$ of respondents strongly agreed that Isaro programme offers access to credit. The mean of 1.185 and $85(87.6 \%)$ of respondents strongly agreed that Isaro programme has group saving scheme as a service offered to rural women. Since the total mean of 1.188 tends towards strongly agree (1) this implies that Isaro Programme offers income generating services to rural women to empower them.

The results have revealed that Isaro programme offered income generating services to rural women such as capacity building, accessibility to credit and group saving scheme which empowered them. These results are supported by the finding of Mukamana (2012) who revealed that the services offered to craftswomen through training in business, marketing and fair pricing have empowered them. It is also supported by the findings of Rana, Ali and Sana (2012) who revealed that education and credit acquired from microfinance considerably influence the empowerment of women.

Table 4. 2: Other Services offered to rural women in Isaro Programme

\begin{tabular}{lllllll}
\hline $\begin{array}{l}\text { Perceptions on other } \\
\text { services }\end{array}$ & $\mathbf{5}$ & $\mathbf{4}$ & $\mathbf{3}$ & $\mathbf{2}$ & $\mathbf{1}$ & Mean \\
\hline $\begin{array}{l}\text { Mutuelle de Sante } \\
\text { Domestic animals }\end{array}$ & $0(0.0)$ & $1(1.0 \%)$ & $2(2.1 \%)$ & $10(10.3 \%)$ & $84(86.6 \%)$ & 1.1753 \\
Family assets & $0(0.0)$ & $1(1.0 \%)$ & $2(2.1 \%)$ & $10(10.3 \%)$ & $84(86.6 \%)$ & 1.1753 \\
School fees & $0(0.0)$ & $2(2.1 \%)$ & $2(2.1 \%)$ & $10(10.3 \%)$ & $83(85.6 \%)$ & 1.2062 \\
Houses & $0(0.0)$ & $2(2.1 \%)$ & $3(3.1 \%)$ & $17(17.5 \%)$ & $75(77.3 \%)$ & 1.4948 \\
Food & $0(0.0)$ & $1(1.0 \%)$ & $2(2.1 \%)$ & $10(10.3 \%)$ & $84(86.6 \%)$ & 1.1753 \\
Total mean & & & & & & 1.24126 \\
\hline
\end{tabular}

Source: Primary Data, 2021

The Table 4.1 indicates that mean of 1.1753 and $84(86.6 \%)$ of respondents strongly agreed that Isaro programme offers mutuelle de santé as a service to rural women. The mean of 1.1856 and 85 (87.6\%) of respondents strongly agreed that Isaro programme offers domestic animals to rural women. The results indicate that 1.2062 and 83(85.6\%) of respondents strongly agreed that Isaro Programme offers school fees to the children of rural women. The results also indicate that mean of 1.4948 and $75(77.3 \%)$ of respondents strongly agreed that Isaro programme constructs houses to rural women and mean of 1.1753 and $84(86.6 \%)$ of respondents strongly agreed that Isaro programme offers food stuffs to rural women. Since the total mean of 1.24126 tends towards strongly agree this implies that Isaro Programme offers other services to rural women to empower them. 
The results indicate that women in rural areas of Huye District were offered with services that empowered them. Thus, this study is supported by the study of Mukamana (2012) who revealed that the services offered to craftswomen regarding pricing fairly and training the individuals in product development which eases the accessibility to the local and international market, better marketing strategies, business management, and selfconfidence have empowered them to possess economic income, the acquisition of productive resources and the development in socio-political positions at both family and levels of community.

\subsection{Effects of Isaro programme on level of income and improved livelihood}

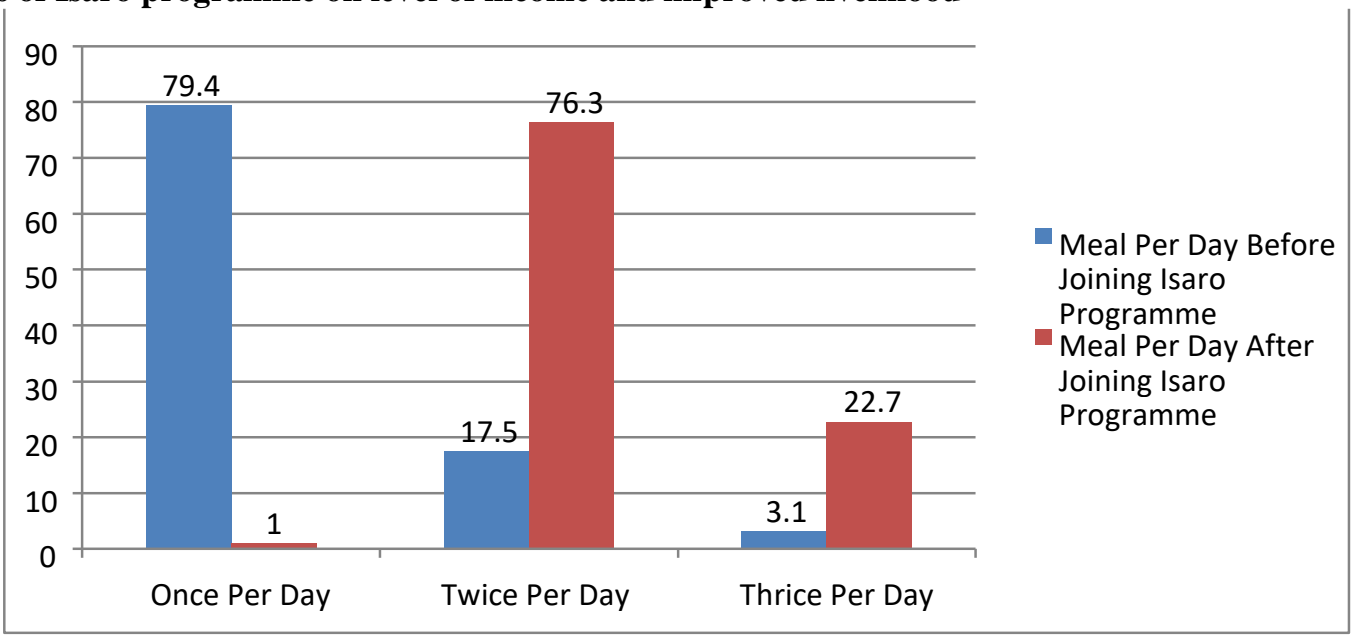

Figure 4. 1: Number of Meal per Day before and after joining Isaro Programme

Source: Research Data, 2021

Results in Figure 4.1 have proved that 77 (79.4\%) respondents got one meal per day before joining Isaro programme while only $1(1.0 \%)$ of respondents get one meal per day after joining Isaro Programme. The results also show that 17 $(17.5 \%)$ of respondents got two meals per day before joining Isaro programme whereas $74(76.3 \%)$ of respondents get two meals per day after joining Isaro programme. The results have also revealed that $3(3.1 \%)$ of respondents got three meals per day before joining Isaro programme while after joining Isaro programme the people who get 3 meal per day increased to $22(22.7 \%)$ of respondents. Thus, it shows that a big number of beneficiaries had to get one meal per day 77 $(79.4 \%)$. Whereas, the number of respondents who get two meals per day after joining Isaro programme have increase to $77(76.3 \%)$ in Huye District, Rwanda.

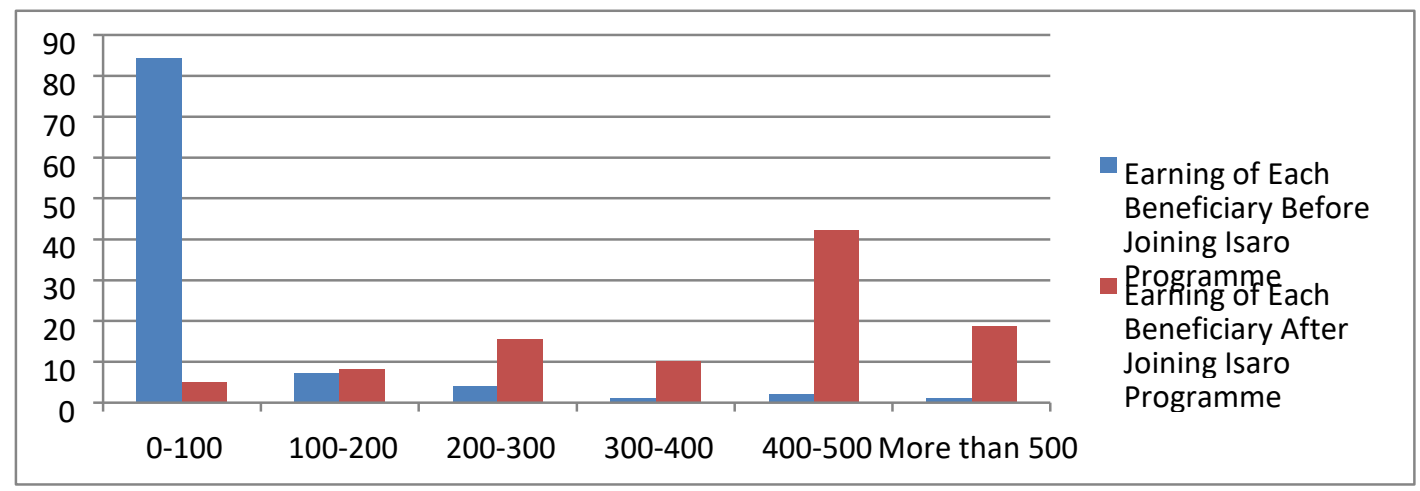

Figure 4. 2: Earning (in Thousands) of each Beneficiary before and after joining Isaro programme Source: Research Data, 2021

The figure 4.1 demonstrates that $82(84.5 \%)$ of respondents before joining Isaro programme earned from 0 to 100000 Rwf whereas only 5 (5.2\%) of respondents earned them after joining Isaro programme. The results also indicate that those who earned between 100000 to 200000 have only 1\% (7.2-8.2\%) between before and after joining Isaro programme. The results have also indicated that $4(4.1 \%)$ of respondents before joining Isaro programme earned from 200000 to 300 000 Rwf whereas $15(15.5 \%)$ of respondents earned them after joining Isaro programme. The results have also revealed that $1(1.0 \%)$ of respondents before joining Isaro programme earned from 300000 to 400000 Rwf to rural women, whereas $10(10.3 \%)$ of respondents earned them after joining Isaro programme. The results also show that $2(2.1 \%)$ of respondents before joining Isaro programme got from 400000 to 500000 Rwf to rural women, whereas after joining Isaro Programme $41(42.3 \%)$ of respondents earned them after joining Isaro programme. The results have also indicated that $1(1.0 \%)$ of respondents before joining Isaro programme earned more than 500000 Rwf whereas, $18(18.6 \%)$ of respondents earned them after joining Isaro programme. Hence, this indicates that a big number of respondents before joining Isaro programme earned from 0 to $100000 \mathrm{Rwf}$ whereas after joining Isaro programme they earned from 400000 to 500000 Rwf in Huye District, Rwanda. 


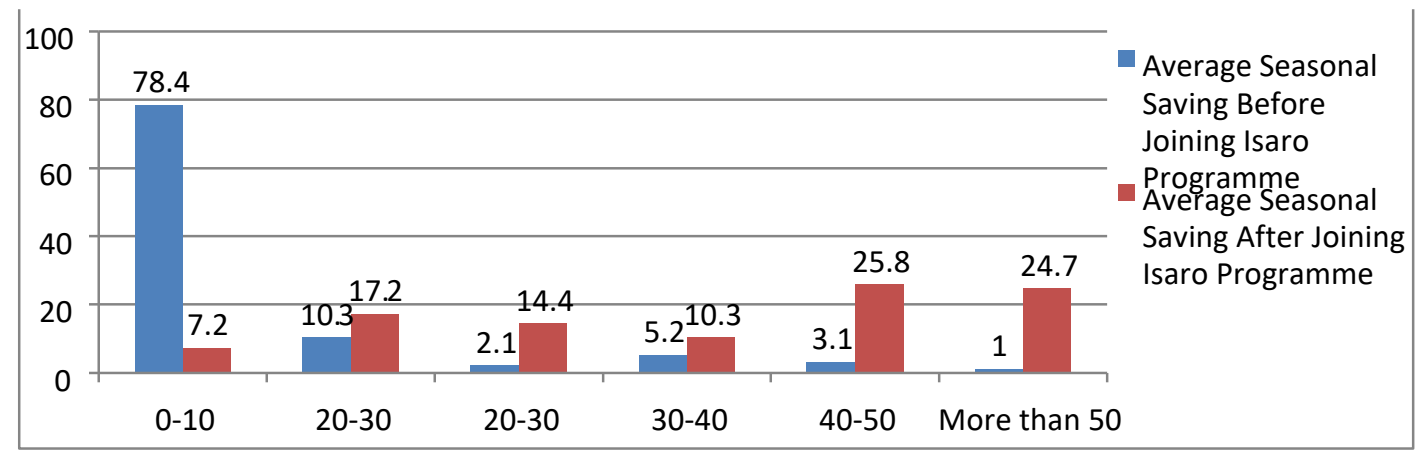

Figure 4. 3: Average Seasonal Saving before and after joining Isaro programme

Source: Research Data, 2021

The figure 4.3 indicates that $76(42.3 \%)$ of respondents before joining Isaro programme saved seasonal average of money from 0 to $10000 \mathrm{Rwf}$ to rural women, $10(10.3 \%)$ of respondents before joining Isaro programme saved seasonal average of money from 10000 to 20000 Rwf to rural women, 5 (5.2\%) of respondents before joining Isaro programme saved seasonal average of money from 30000 to $40000 \mathrm{Rwf}$ to rural women, 3 (3.1\%) of respondents before joining Isaro programme got from 40000 to 50000 Rwf to rural women, 2 (2.1\%) of respondents before joining Isaro programme saved seasonal average of money from 20000 to 30000 Rwf to rural women, $1(1.0 \%)$ of respondents before joining Isaro programme saved seasonal average of money more than $50000 \mathrm{Rwf}$ to rural women.

Whereas, $25(25.8 \%)$ of respondents after joining Isaro programme saved seasonal average of money from 40000 to 50 $000 \mathrm{Rwf}$ to rural women, $24(24.7 \%)$ of respondents after joining Isaro programme saved seasonal average of money more than $50000 \mathrm{Rwf}$ to rural women, 17 (17.5\%) of respondents after joining Isaro programme saved seasonal average of money from 10000 to $20000 \mathrm{Rwf}$ to rural women, 14 (14.4\%) of respondents after joining Isaro programme got from 20000 to $30000 \mathrm{Rwf}$ to rural women, 10 (10.3\%) of respondents after joining Isaro programme saved seasonal average of money from 20000 to $30000 \mathrm{Rwf}$ to rural women, 7 (7.2\%) of respondents after joining Isaro programme saved seasonal average of money from 0 to $10000 \mathrm{Rwf}$ to rural women. Hence, this indicates that a big number of respondents before joining Isaro programme saved seasonal average amount of money from 0 to $10000 \mathrm{Rwf}$ whereas after joining Isaro programme saved seasonal average of money from 40000 to 50000 Rwf to rural women in Huye District, Rwanda

4.3 Rural women's involvement in decision making before and after care international, Isaro programme Table 4. 3: Correlation analysis between NGOs income generation services and rural women empowerment in Rwanda

\begin{tabular}{|c|c|c|c|c|}
\hline & & $\begin{array}{l}\text { Participation in } \\
\text { Economic } \\
\text { Activities } \\
\end{array}$ & $\begin{array}{l}\text { Participation in } \\
\text { family Decision } \\
\text { making }\end{array}$ & $\begin{array}{l}\text { Improving } \\
\text { live hoods }\end{array}$ \\
\hline \multirow{5}{*}{$\begin{array}{l}\text { Group } \\
\text { Scheme }\end{array}$} & Pearson & $.822^{* *}$ & $.819^{* *}$ & $.875^{* *}$ \\
\hline & Correlation & .000 & .000 & .000 \\
\hline & $\begin{array}{l}\text { Sig. } \\
\text { tailed) }\end{array}$ & & & \\
\hline & $\mathrm{N}$ & 97 & 97 & 97 \\
\hline & Pearson & $.767^{* *}$ & $.764^{* *}$ & $.818^{* *}$ \\
\hline \multirow[t]{3}{*}{$\begin{array}{l}\text { Accessibility to } \\
\text { credit }\end{array}$} & $\begin{array}{l}\text { Correlation } \\
\text { Sig. (2- } \\
\text { tailed) }\end{array}$ & .000 & .000 & .000 \\
\hline & $\mathrm{N}$ & 97 & 97 & 97 \\
\hline & Pearson & $.753^{* *}$ & $.750^{* *}$ & $.804^{* *}$ \\
\hline \multirow{3}{*}{$\begin{array}{l}\text { Capacity } \\
\text { building } \\
\text { through training }\end{array}$} & Correlation & .000 & .000 & .000 \\
\hline & $\begin{array}{l}\text { Sig. } \\
\text { tailed) }\end{array}$ & & & \\
\hline & $\mathrm{N}$ & 97 & 97 & 97 \\
\hline
\end{tabular}

**. Correlation is significant at the 0.01 level (2-tailed).

Source: Research Data, 2021

The Table 4.3 have proven a positively significant relationship between group saving scheme and participation in family economic development activities that has a Pearson correlation of 0.822 with calculated 0.00 level of significance which is less than 0.01 level of significance, between group saving scheme and participation in family decision making with Pearson correlation of 0.819 and calculated 0.00 significance value which is less than 0.01 level of significance. Thus, as indicated in the table the results show a positive and significant relationship between NGOs income generating services and empowerment of rural women in CARE international, Isaro Programme in Huye District, Rwanda. 
Therefore, comparing the above results proving that there is a positive and significant relationship between NGOs income generating services and empowerment of rural women in Huye District with the results of the study of Mushumbusi and Kratzer (2013) in Tanzania, their study has revealed that through the use of Mann- Whitney U test. There is a significant difference between women members of microfinance income generating services and non-members. The facts are grounded on the results showing that women members have more control over saving, income generating business, taking role in decision making, have freedom of mobility, selfesteem and self-efficacy and increased activities outside home. The same results proving positive and significant relationship between NGOs income generating service and empowerment of rural women are supported by the study which proved that microfinance programs for women has a positive relationship with economic growth due to the increase of women's income generating services as per Hunt and Kasynathan (2002). The findings also confirmed an impact of microcredit in education of men to women, self-respect, marital practice and mobility. The study also has shown that donors and NGOs need to pay attention and focused on poorest people on accessibility to credit.

Table 4. 4: Coefficients of NGOs Income Generating Services as independent variable and Participation of Rural Women in Family Economic Development activities

\begin{tabular}{|c|c|c|c|c|c|}
\hline \multirow[t]{2}{*}{ Model } & \multicolumn{2}{|c|}{$\begin{array}{l}\text { Unstandardized } \\
\text { Coefficients }\end{array}$} & $\begin{array}{l}\text { Standardized } \\
\text { Coefficients }\end{array}$ & $\mathrm{T}$ & \multirow[t]{2}{*}{ Sig. } \\
\hline & $\mathrm{B}$ & Std. Error & Beta & & \\
\hline (Constant) & .261 & .190 & & 1.370 & .174 \\
\hline Group Saving Scheme & .484 & .118 & .476 & 4.092 & .000 \\
\hline Accessibility to credit & .217 & .105 & .216 & 2.076 & .041 \\
\hline $\begin{array}{l}\text { Capacity building through } \\
\text { training }\end{array}$ & .208 & .099 & .205 & 2.098 & .039 \\
\hline
\end{tabular}

a. Dependent Variable: Participation in Family Economic Development Activities

Source: Research Data, 2021

The Table 4.4 proves that NGOs income generating predictors have positive coefficients implying that they have positive effect on participation of rural women in family economic development services. Thus, the analysis of regression prove that NGOs income generating services and participation of rural women in family economic development services has a positively significant relationship because all calculated p-values are lesser than 0.05 level of significance.

Therefore, the model of regression coefficient $\mathrm{Y}=\beta 0+\beta 1 \mathrm{X} 1+\beta 2 \mathrm{X} 2+\beta 3 \mathrm{X} 3$ representing $\mathrm{Y}=.261+484 \mathrm{X} 1+.217 \mathrm{X} 2+.208 \mathrm{X} 3$ implying that NGOs income generating services and participation rural women in family economic development activities has a positively significant relationship, in CARE international, Isaro programme. Thus, the results of this study is compared to that of the study of Salma, et al., (2020) who asserted that development projects conducted by government and NGOs have played a significant role to providing training, awareness and credits to rural women which raised the economic standards of their families and that of South and North regions of Pakistan.

The first objective of establishing the relationship between group saving scheme and participation of rural women in family economic development activities has a relationship which is positive and significant $(b=0.484$ and $p=0.00)$ because the calculated p-value is less than 0.05 level of significance. The second objective of establishing the relationship between accessibility to credit and participation of rural women in family economic development activities has a positive and significant relationship $(b=0.217$ and sig=0.041) because calculated pvalue is less than 0.05 level of significance. The third objective of establishing the relationship between capacity building through training and participation of rural women in family economic development activities has a positive relationship $(b=0.208$ and $p=0.039)$ because calculated p-value is less than 0.05 significance level. It shows that there is a positive significant relationship between NGOs income generating services and participation of rural women in family economic development services in CARE international, Isaro programme in Huye District, Rwanda.

Table 4. 5: Coefficients of NGOs Income Generating Services as independent variable and participation of rural women in familv decision making

\begin{tabular}{|c|c|c|c|c|c|}
\hline \multicolumn{3}{|c|}{ Model Unstandardized Coefficients } & Standard & \multirow[t]{2}{*}{$T$} & \\
\hline $\mathrm{B}$ & Std. Error & & Beta & & \\
\hline (Constant) & .384 & .075 & & 5.135 & .000 \\
\hline Budgeting & -.071 & .077 & -.073 & -.911 & .005 \\
\hline Training & .873 & .219 & .892 & 3.989 & .000 \\
\hline Accountabil & .077 & .202 & .081 & .381 & .004 \\
\hline
\end{tabular}

a. Dependent Variable: Timely completion of the project

Source: Research Data, 2021

The Table 4.5 proves that NGOs income generating predictors have positive coefficients implying that they have positive effect on participation of rural women in family economic development services. Thus, the analysis of regression prove 
that NGOs income generating services and participation of rural women in family economic development services has a positively significant relationship because all calculated p-values are lesser than 0.05 level of significance.

Therefore, the model of regression coefficient $Y=\beta_{0}+\beta_{1} X_{1}+\beta_{2} X_{2}+\beta_{3} X_{3}$ representing $Y=.261+484 X_{1}+.217 X_{2}+.208 X_{3}$ implying that NGOs income generating services and participation rural women in family economic development activities has a positively significant relationship, in CARE international, Isaro programme. Thus, the results of this study is compared to that of the study of Salma, et al., (2020) who asserted that development projects conducted by government and NGOs have played a significant role to providing training, awareness and credits to rural women which raised the economic standards of their families and that of South and North regions of Pakistan.

The first objective of establishing the relationship between group saving scheme and participation of rural women in family economic development activities has a relationship which is positive and significant $(b=0.484$ and $p=0.00)$ because the calculated p-value is less than 0.05 level of significance. The second objective of establishing the relationship between accessibility to credit and participation of rural women in family economic development activities has a positive and significant relationship $(b=0.217$ and sig $=0.041)$ because calculated pvalue is less than 0.05 level of significance. The third objective of establishing the relationship between capacity building through training and participation of rural women in family economic development activities has a positive relationship $(b=0.208$ and $p=0.039)$ because calculated p-value is less than 0.05 significance level. It shows that there is a positive significant relationship between NGOs income generating services and participation of rural women in family economic development services in CARE international, Isaro programme in Huye District, Rwanda.

Table 4. 6: Coefficients of NGOs Income Generating Services as independent variable and participation of rural women in family decision making

\begin{tabular}{llllll}
\hline Model & \multicolumn{2}{l}{ Unstandardized Coefficients } & Standardized Coefficients & & \multirow{2}{*}{ S Sig. } \\
\cline { 2 - 5 } & $\mathrm{B}$ & Std. Error & Beta & & \\
\hline (Constant) & .354 & .074 & & .792 & .000 \\
Budgeting & -.061 & .077 & .061 & -.800 & .004 \\
Training & .139 & .216 & .137 & .642 & .003 \\
Accountability & .822 & .200 & .835 & 4.108 & .000 \\
\hline
\end{tabular}

a. Dependent Variable: Level of satisfaction of beneficiaries

Source: Research Data, 2021

The Table 4.6 proves that NGOs income generating services and participation of rural women in family decision making has a positive significant relationship because all calculated $\mathrm{p}$-values are lesser than level of significance which is 0.05 . Hence, $Y=\beta 0+\beta 1 \mathrm{X} 1+\beta 2 \mathrm{X} 2+\beta 3 \mathrm{X} 3+\beta$ regression model becomes

$\mathrm{Y}=0.317+0.484 \mathrm{X} 1+0.213 \mathrm{X} 2+0.203 \mathrm{X} 3$ showing that there is a positive significant relationship between NGOs income generating services and participation of rural women in family decision making, in CARE international, Isaro programme. The first objective of establishing the relationship between group saving scheme and the participation of rural women in family decision-making has a positive relationship $(b=0.484$ and $p=0.004)$ because the calculated $p$-value is less than 0.05 significance level. The second objective of organizing the relationship between accessibility to the credit and the participation of rural women in family decision $(b=0.213$ and $\operatorname{sig}=0.045)$ proving a significant relationship because the calculated p-value is less than 0.05 level of significance. Third organizing objective between capacity building and participation of rural women in family decision making $(b=0.203$ and $p=0.044)$ because the calculated $p$-value is less than the value level of 0.05 . It therefore implies that there is a positive and significant relationship between the benefits of NGOs income generating services and the participation of rural women in family decision-making of CARE international, Isaro programme in Huye District, Rwanda.

The results of this study stating that there is a significant positive relationship between the benefits of NGOs income generating services and the participation of rural women in decision -making is compared with the results of Mushumbusi and Kratzer (2013) which supports this relationship because in their findings they have also found that women members of microfinance income generating services have got control over saving, income generating services and got role to play in decision making process at home and outside home.

\subsection{Conclusion}

The results of current study proved that there is a relationship between group saving scheme and participation in family economic development services which has Pearson correlation of .731 and calculated significance value of .000 which is under 0.01 level of significance, between accessibility to credit and capacity building through training which has a Pearson correlation of .711 and calculated significance value of .000 which is under 0.01 level of significance. This proves that there is relationship between NGOs income generation services and rural women empowerment in CARE international, Isaro programme in Huye District, Rwanda.

The aforementioned results show that NGOs income generation services play a big to ensure rural women empowerment through group saving scheme, access to credit and training that is reinforced by participation in family economic development activities, participation in family decision making and improving livelihoods. Briefly, the results show that the rural women known as Isaro programme in this study benefits a lot from the programme that enhance the economic 
development of their households, having part in making decisions for the family because they are also productive to the family and improving livelihoods of the family members.

\subsection{Acknowledgement}

I would like to thank my family, co-workers, friends and other people for their help to ensure that my studies and this research are accomplished. My thanks and a lot of appreciations should go to my husband Major Charles Sumanyi for love, kindness, advice, support and encouragement that enabled me to complete this study. I can never forget the contribution of CARE international and the respondents of the study for their information given to me to be able to successful complete this work.

\section{References}

[1].African Development Bank Group. (2008). ADBG Gender assessment: progress towards improving women's economic status. Kigali: Africand Development Bank.

[2].Buchards, A. (1992). Statistique appliquée à la Géographie. Paris: Bards.

[3].CARE International. (2008). Isaro Programme Document. Kigali: CARE International.

[4].Carson, K. \& Randall, S. (2013). Gender and Development: Working with Men for Gender Equality in Rwanda. Agenda 95/27: 114-125.

[5].Hunt, J. \& Kasynathan, N. (2002). Reflections on microfinance and women 's empowerment. Development Bulletin, $57,71-75$.

[6].Ministry of Gender and Family Promotion (2016). MIGEPROF Final Report of The Strategy on Women and Youth Access to Finance (2016-2020). Kigali, Rwanda.

[7].Ministry of Gender and Family Promotion, (2011). Rwanda Cooperative Agency and Business Development. MIGEPROF. Kigali, Rwanda.

[8].Mukamana, L. (2012). The Contribution of Women Organizations to the Economic Empowerment of

[9].Craftswomen: Case Study of The National Association of Women Organizations in Uganda. Rwanda Journal, 26 (98), 1014-4874. DOI : http://dx.doi.org/10.4314/rj.v26i1.5

[10]. Mushumbusi, P. \& Kratzer, J. (2013). Empowering Women through Microfinance: Evidence from Tanzania. ACRN Journal of Entrepreneurship Perspectives. 2 (1), 31-59.

[11]. Mushumbusi, P. K. \& Kratzer, J. (2013). Empowering Women through Microfinance: Evidence from Tanzania. ACRN Journal of Entrepreneurship Perspectives, 2 (1), 31-59.

[12]. Noreen, S. (2011). Role of Microfinance in Empowerment of Female Population. Illinois. Chicago. USA

[13]. Pyakuryal, K. \& Suvedi, M. (2000). Understanding Nepal's development: Context, interventions and people's aspirations. Michigan State University Department of Agriculture and Natural Resources Education and Communication Systems. Michigan, USA.

[14]. Rana, E. Ali, K. \& Sara, N. (2012). Microfinance and women empowerment: A case study of District Bahawalpur in Pakistan. African Journal of Business Management, 6(12), 4514-4521, 28 March, 2012 DOI: 10.5897/AJBM11.2407.

[15]. Roshani, D. (2010). Women Empowerment through Income Generation Programme at a Village Development Committee in Lalitpur District of Nepal. Bangladesh: North South University.

[16]. Salma, J., Sanam, H., Arif, J., Abid, H., Muhammad, A., Jinsoo, H. \& Abida, J. (2020). Impacts of Rural Women's Traditional Economic Activities on Household Economy: Changing Economic Contributions through Empowered Women in Rural Pakistan. Journal of Sustainability, 12 (20), 27-31; doi:10.3390/su12072731

[17]. Shalakha, R. \& Shivani, K. (2016). Role of Income Generation Programme in Women Empowerment. Journal of Enterpreneurship and Innovation, 3(2). 211-224. DOI: 10.21844/smsjei.v2i2.11147

[18]. Thanabalasingam, V. Asankha, P. (2014). Impacts of NGO intervention on poverty reduction: an empirical evidence from rural Sri Lanka. International Journal of Sustainable Economy,6 (3), 288 - 301. DOI: 10.1504/IJSE.2014.063181 